\title{
MacNiven v Westmoreland Investments Limited and the implications for self-administered pension schemes \\ Received: 23rd May, 2001
}

\section{John Hayward}

is a Senior Pension Consultant with Carr Sheppards Crosthwaite Limited. He was formerly a principal in the Pension Schemes Office (PSO) and has spent 13 years in pensions consultancy. He lectures and writes frequently on pension matters with regular monthly articles in Tax Journal since 1993. His book, 'SSAS - SIPPS - FURBS', published by Tolleys in 1999 (fourth edition) is the leading work on small self-administered pension schemes, self-invested personal pension schemes and funded unapproved retirement benefit schemes.

John Hayward Pension Consultant, Carr Sheppards Crosthwaite Limited, Clock House, Dogflud Way, Farnham, Surrey GU9 7UL, UK.

Tel: +44 (0)1227 629 246; e-mail: mhumphrey@ carr-sheppards.co.uk

\begin{abstract}
The tax case of MacNiven (HMIT) v Westmoreland Investments Limited, finally decided in the House of Lords in February 2001, ${ }^{1}$ referred to hereafter as MacNiven $v$ WIL, does not directly involve a pension scheme as either the appellant or defendant. The point at issue was the status of WIL: was it an investment or trading company for tax purposes and was tax avoidance involved in the arrangements carried out to improve its financial position? Its relevance for pension schemes is that WIL is a wholly owned subsidiary of a company in turn wholly owned by the trustees of a large self-administered pension scheme, the Electricity Supply Pension Scheme. This paper explores the circumstances surrounding the tax case at each stage, from the initial hearing before the Special Commissioners right the way to the House of Lords, as they need to be understood to appreciate the implications they have for all tax approved self-administered pension schemes, particularly small self-administered schemes (SSAS). The paper then goes on to discuss what those implications are especially when the trustees of pension schemes make injudicious and interest-free loans, particularly the conflict with Inland Revenue requirements for SSAS, and the relevance of apparently excessive employer-related investments since 1992.
\end{abstract}

Keywords: tax avoidance; Ramsay principle; injudicious and interest-free loans; SSAS; employer-related investments

\section{The facts}

In the 1980s WIL got into financial difficulties. WH Cork Gully \& Co were asked to advise the pension scheme trustees and produced a report in February 1980 written by 'Businessmen for Businessmen' for winding down the company's business. The continued support of the pension scheme was needed to produce the best result, and the trustees took the view they had no real alternative but to support WIL; 'continuing the business as a going concern avoided the dangers of forced sale realisations'. ${ }^{2}$

So began a series of loans by the trustees to WIL beginning with $£ 9.5$ million on 31st March, 1980 at 17 per 
cent interest, which was repaid on 31st March 1992. A further $\mathcal{K}^{1.9 \mathrm{~m}}$ was loaned on 31st December, 1980. Numerous other loans were made so that by 31st March, 1987 WIL owed the trustees f73,747,758, including $\mathcal{N}^{42,206,307}$ interest accrued but unpaid.

Loans were not serviced in full. On 27th January, 1988 the trustees 'resolved that funds be made available to enable WIL to repay the pension scheme interest of $f^{20 m}$ gross'. ${ }^{3}$ On 17 th August, 1989 the scheme advanced $£ 69,911,565$ to WIL interest-free, and WIL paid $\mathcal{E}^{62,316,580}$ to the trustees, representing capital and their interest repayments. On 3rd January, 1990 the scheme advanced $£ 34,500,000$ to WIL interest-free, and WIL paid $£ 27,585,107$ to the trustees representing capital and interest payments. These interest-free loans were recommended by the trustees' advisers to allow WIL to purchase the property investment.

\section{Special Commissioners findings}

The case was first heard before the Special Commissioners in late 1996 on an appeal by WIL that it was a trading company and entitled to allowable deductions for interest paid. The Special Commissioners found that all the loans made to WIL were real loans and used for real purposes. They agreed with WIL's contention that the object of the refinancing was to crystallise the actual loss by paying interest which until then have merely been accrued and not paid. They held that the interest had been paid and gave rise to an allowable deduction for Corporation Tax purposes as WIL was a trading company. ${ }^{4}$

\section{High Court findings}

The Inland Revenue appealed against the Special Commissioner's decision and the case was heard in the High Court in 1997. The Inland Revenue submitted that the transfer of funds by the scheme to WIL, and the transfer of funds by WIL to the scheme, were not normal transactions between businessmen. The High Court Judge agreed, adding that, 'they were part of a pre-planned tax saving scheme whereby the pension scheme lent money to the company to enable it to pay off loans earlier and accrued interest. ${ }^{5}$

The Judge went on to say, 'the proported payments had been effected by an artificial circulation of money designed purely for the purposes of tax advantage'. Importing the Ramsay ${ }^{6}$ principle he said, 'the arrangements, whereby the loans made in the early 1980s were replaced by new loans, were a pre-ordained series of transactions. What mattered was that the arrangements for transfer of funds from the scheme to the company and back again to the scheme were steps inserted for no commercial purpose apart from avoidance of liability to tax. The critical factor, from the point of view of the Ramsay principle, was that the transactions had been inserted for no other reason than the reduction of tax liability'. The High Court ruled that WIL was an investment company. ${ }^{7}$

\section{Court of Appeal findings}

WIL appealed against the High Court decision and the case was heard in the Court of Appeal in October 1998, resulting in the reversal of the High Court judgment. The Court of Appeal held that WIL was a trading company and not an investment company as held by the High Court. ${ }^{8}$ The Ramsay principle, importing tax avoidance to the various transactions between the trustees and WIL, was overturned.

The Court of Appeal concluded that 
'what was done in the instant case did not fall within the category of tax avoidance to which the Ramsay principle applied. There was a distinction between unacceptable tax avoidance and acceptable tax mitigation ... the Ramsay principle did not therefore apply to the payment of interest by WIL to the trustees in discharge of a genuine liability'.

\section{House of Lords findings}

The Inland Revenue appealed against the Court of Appeal decision and the case was heard in the House of Lords in February 2001 resulting in the decision of the Court of Appeal being upheld, ie, WIL was a trading company. ${ }^{9}$

The Ramsay principle importing tax avoidance to the various transactions between the trustees and WIL was the cornerstone of the Inland Revenue's case. It argued that the transactions had no commercial purpose and were purely for the purpose of avoiding tax, so should be disregarded. However, the House of Lords noted that the trustees' advisers had recognised there might be value to a purchaser in WIL's tax losses which would crystallise as if the arrears of interest were paid. The further loans had enabled the accrued interest to be paid and tax deducted from the interest had been reclaimed. All these transactions were real and commercial involving the 'genuine discharge of a genuine debt' and therefore qualified as payments of interest. The fact that tax was deductible from the interest and reclaimable by the trustees did not mean the transactions were solely to secure a tax advantage. The Inland Revenue's argument that Ramsay applied was dismissed.

\section{Implications for pension schemes}

Had the tax avoidance argument maintained by the High Court been sustained at the higher Court levels, the Electricity Supply Pension Scheme may well have been seen by the PSO as being used as a vehicle to achieve tax avoidance and therefore offending the statutory sole purposes test for tax approval. ${ }^{10}$ Nonetheless, until the Court of Appeal decision, the situation must have caused the PSO some embarrassment as withdrawal of tax approval, the usual course if tax avoidance is involved, is unheard of regarding large self-administered schemes, the repercussions for the membership would have been horrendous. Fortunately for the PSO, the Court of Appeal and House of Lords decisions quashed the tax avoidance argument and consequently any need for the PSO to consider withdrawing the scheme's tax approval on that front.

However, the question of how the trustees exercised their fiduciary powers in the best interests of the members of the pension scheme must also have exercised, and may still be exercising, the PSO's mind. Of course the case reports tell us nothing of this because the PSO was not involved directly in the case and it will probably never be known, for reasons of confidentiality, what the PSO has done, if anything. The question must remain though: did the trustees here act in the best interests of the members of the pension scheme? This is extremely important because trustees of other large self-administered pensions schemes, and particularly trustees of SSAS (see later), may well be in a similar situation and McNiven $v$ WIL may provide useful pointers for them in arguing their case with the PSO. Were the trustees here throwing good money after bad to a known financially ailing company, or were the refinancing arrangements proposed by independent advisers and adopted sufficient to show that the trustees acted properly in their fiduciary 
capacity? The author will leave readers to discuss the answers for themselves, but it should be noted that the refinancing arrangements did not apparently clear the total indebtedness of WIL to the trustees.

We are also left in the dark as to whether the PSO has taken or will take any action to enforce the payment of interest on interest-free and unpaid loans. It has the power to do this in the surplus legislation $^{11}$ and to raise a 40 per cent tax charge on the company debtor if interest is not paid because a loan must show a reasonable return. The PSO may well have known nothing of this case until it reached the Courts in 1996 and/or be time-barred by the 6-year rule on assessment. This legislation is only effective back to 1987 anyway, so loan interest unpaid prior to then or taxed thereon at 40 per cent would be lost. This aspect will be briefly explored later in this paper.

\section{Implications for SSAS}

For a considerable number of years now the PSO has been pursuing the trustees of SSAS where loans have been made injudiciously to financially ailing companies, where loans have been made interest-free, and where interest on loans has not been fully serviced. In many cases this has led to loss of the scheme's tax approval or refusal to approve the scheme. The amounts involved in these cases are overwhelmingly smaller than those lent to WIL. The trustees of SSAS may therefore feel justifiably aggrieved at the inequitable treatment the PSO has applied to them in comparison apparently to the Electricity Supply Pension Scheme. The trustees of SSAS are required to act in the best interests of their members and not make loans to ailing companies. Borrowing companies are required to pay interest on loans made to them ${ }^{12}$ and no loans are permitted interest-free. Indeed where loans are renewed, accrued interest to date must be repaid..$^{13}$ In addition loans must be for a commercial purpose ${ }^{14}$ and not to enable earlier loans to be repaid. ${ }^{15}$

In contrast, in MacNiven $v$ WIL, loans were used to prop up an ailing company and to repay earlier loans. In the Court of Appeal it was noted that, 'it was in WIL's commercial interest to refinance its indebtedness because of the burdensome rates of interest chargeable on those loans ... creditors and debtors with accrued interest liabilities not infrequently renegotiated those liabilities. They may do so by a further increased loan coupled with the repayment of the accrued interest. Frequently a debtor refinanced his debt including any accrued interest liability by borrowing an increased sum so as to discharge that debt ... the fact that the original creditor provided the funding to discharge the accrued interest liability to it did not make the payment of that interest not a reality'.

In the author's view, any SSAS which has had its tax approval withdrawn or refused or is under threat currently of such action, because of injudicious loans, interest-free loans or loans where interest has not been paid in full, is entitled to argue its case with the PSO quoting such extracts as these and others from McNiven $v$ WIL in support of its own case. The Taxpayers Charter requires the Inland Revenue, which includes the PSO, to treat all taxpayers equally and this in turn includes pension schemes.

\section{Employer-related investments}

In conclusion, a DSS aspect should be considered in conjunction with the MacNiven $v$ WIL case. On 9th March, 1992 the DSS introduced legislation banning employer-related investments by large self-administered pension schemes 
of more than 5 per cent of the value of the fund. ${ }^{16}$ The loans to WIL constitute employer-related investments; and although we know these amounted to over $£ 73 \mathrm{~m}$ by 1987 we do not know from the case reports what was owed at 9th March, 1992 nor its proportion of the whole fund. $673 \mathrm{~m}$, however, is 5 per cent of $\mathcal{f} 1,460 \mathrm{~m}$ and had the fund had a lower value at 9th March, 1992 and such an amount still been on loan, the amount would have had to have been reduced. It may well be that having set in train the refinancing arrangements, which were to enable WIL to be put in the position where it could be sold because its tax losses would be attractive to a purchaser, that WIL was actually sold before 9th March, 1992. Again we do not know, but WIL's purchaser would still have had to take on board the balance of the loans and accrued interest remaining unpaid - the refinancing did not apparently clear all these. Thus the employer-related investment problem would have disappeared, but if the remaining loan balances and interest accrued thereon had been written-off as part of the sale and purchase arrangements, further Inland Revenue surplus implications could have arisen; ${ }^{17}$ but that is another story.

\section{References}

1 [2001] UKHL6.

2 Westmoreland Investments Limited v MacNiven SpC 00109

3 Simon's Weekly Tax Intelligence, 31st July 1997.

4 See 2 above.

5 See 3 above.

6 Ramsay (WT) Ltd. v Commissioners of Inland Revenue [1982] AC300.

7 See 3 above.

8 MacNiven $v$ Westmoreland Investments Limited [1999] STC1103.

9 See 1 above.

10 Section 590(2) (a) Income \& Corporation Taxes Act 1988.

11 Pension Schemes Surpluses (Administration) Regulations 1987 No: 352 (4) (a) (iii).

12 Retirement Benefits Schemes (Restriction on Discretion to Approve) (Small Self-Administered Schemes) Regulations 1991 No: 1614 (5) (2).

13 Pension Schemes Office Practice Notes: PN20.33.

14 See 12 above.

15 Small Self-Adminstered Schemes Guidance Notes 9.71 .

16 Occupational Pension Schemes (Investment of Scheme's Resources) Regulations 1992 No: 246.

17 Pension Schemes Surpluses (Administration) Regulations 1987 No: 352 and Section 601 Income \& Corporation Taxes Act 1988. 